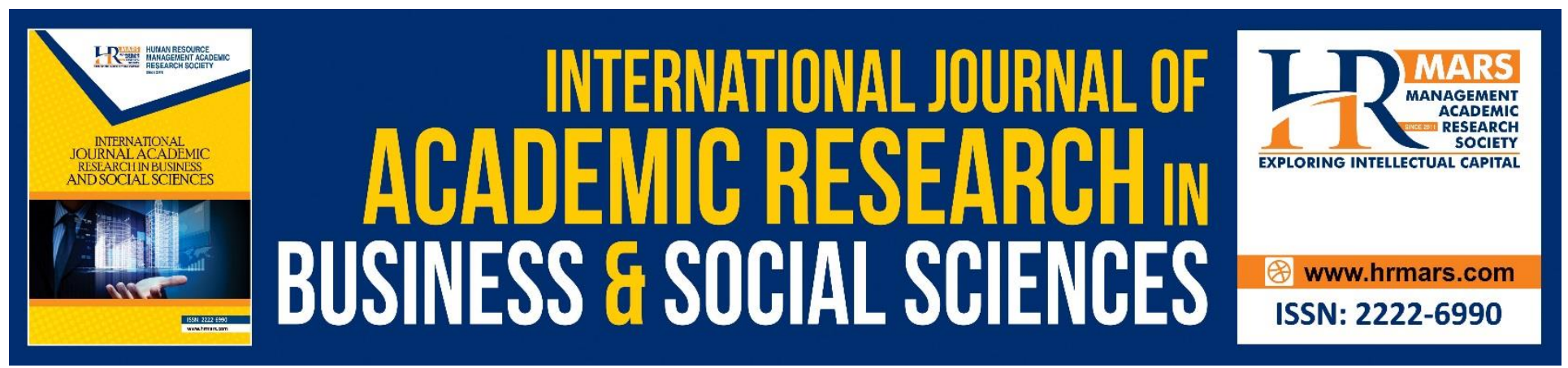

\title{
Factors of Disapproving of Early Marriage in Malaysia
}

Abdul Rauf Ridzuan, Siti Nurshahida Sah Alam, Abdul Rahim Ridzuan, Nadia Mohd Nazri, Muhammad Hakimi Tew Abdullah, Irzan Ismail

To Link this Article: http://dx.doi.org/10.6007/IJARBSS/v8-i10/4789

DOI: 10.6007/IJARBSS/v8-i10/4789

Received: 21 Sept 2018, Revised: 18 Oct 2018, Accepted: 31 Oct 2018

Published Online: 09 Nov 2018

In-Text Citation: (Ridzuan et al., 2018)

To Cite this Article: Ridzuan, A. R., Alam, S. N. S., Ridzuan, A. R., Nazri, N. M., Abdullah, M. H. T., \& Ismail, I. (2018). Factors of Disapproving of Early Marriage in Malaysia. International Journal of Academic Research in Business and Social Sciences, 8(10), 915-926.

Copyright: (c) 2018 The Author(s)

Published by Human Resource Management Academic Research Society (www.hrmars.com)

This article is published under the Creative Commons Attribution (CC BY 4.0) license. Anyone may reproduce, distribute, translate and create derivative works of this article (for both commercial and non-commercial purposes), subject to full attribution to the original publication and authors. The full terms of this license may be seen at: http://creativecommons.org/licences/by/4.0/legalcode

Vol. 8, No. 10, 2018, Pg. 915 - 926

http://hrmars.com/index.php/pages/detail/IJARBSS

JOURNAL HOMEPAGE

Full Terms \& Conditions of access and use can be found at http://hrmars.com/index.php/pages/detail/publication-ethics 


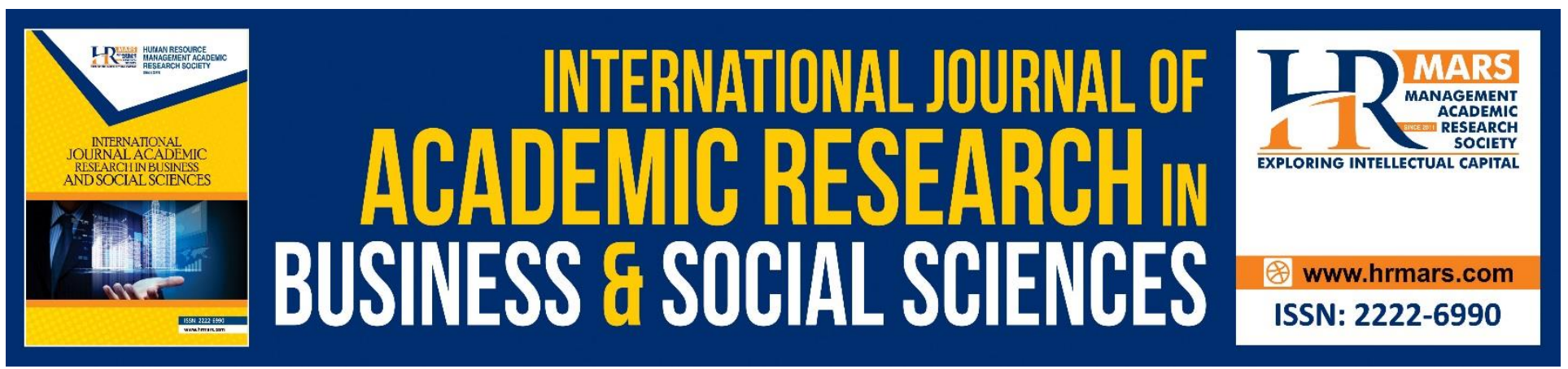

\title{
Factors of Disapproving of Early Marriage in Malaysia
}

\author{
Abdul Rauf Ridzuan, Siti Nurshahida Sah Alam, Abdul Rahim \\ Ridzuan, Nadia Mohd Nazri, Muhammad Hakimi Tew Abdullah, \\ Irzan Ismail \\ Faculty of Communication \& Media Studies, Universiti Teknologi Mara Melaka
}

\begin{abstract}
Early marriage is defined as the marriage between two people in which one or both parties are younger than 18 years of age. Early marriages are also an option for parents as they can protect their daughter's dignity. In addition, many parents agree to marry their daughter at a young age due to financial problems and so on, so they trust the man who will marry their daughter to take care of her. There are two types of early marriage. The first is because of parents' coercion and the second is because of their own will. Nowadays, early marriage has become a trend for young people. This study involved 421 respondents who answered the questionnaires that had been distributed. Based on the findings, the main reasons people disapproved of early marriage are because of financial instability $(\mathrm{M}=3.2)$ and missing out teenage life $(M=2.7)$.
\end{abstract}

Keywords: Early marriage, Financial, Responsibility, Mental and Health

\section{Introduction}

In this age, early marriages have become trends towards young people. This is because today, many young people already have their own job and are able to bear their own families. But there are some young people who are forced to get married early because of their parents' coercion. However, when these young people get married early, there are many disadvantages that often happen in their lives. According to Waters (2018), there are some of the disadvantages that happen in the young married couples. One of them is, they are missing out on the fun of teenage life and being young. The drudgeries of married life can get on to the immature minds. This affects the couples a lot because they do see their friends can still enjoy their teenager life while they have to manage their household. Other than that, new couples usually have a lack of responsibility. Responsibility has to be shouldered at a very young age. One has to take on household responsibilities, take care of the child things and else. There is no adult to guide or help out in case the couple is living alone. This will make them more stressful in their life. But early marriage also has its own advantages. According to Early Marriage (2018), the advantages of early marriage are, it will help to develop mental capabilities. It is the duty of a husband to go out and work for money to support their family. This is a must as he has to raise the family. In the same way, a wife has a responsibility to manage the households and the children. 
When the early marriage takes place, the younger couple would have enough time to develop better mental capabilities so that they can give a new edge to their lives and enjoy a bright future together.

Next, it will help them to boost the energies for success. As compared to the elderly couples who usually do not even have time to think about their lives but profession and earnings to raise the families, the younger couples are more energetic. They can boost their energies more effectively and work hard for a better future together and a successful life ahead. Because they have each other to support what are they going to do. They will easily get motivated to do the things. So basically, early marriage has its own disadvantages and the advantages. So, what is the acceptance of the public towards early marriages?

\section{Problem Statement}

There are a few problems that a couple can face when marriage happened at an early age such as financial problems. Early marriage happens at the age between 16 years old to 25 years old which means that a person has no strong financial to actually build a family yet. They are probably still studying or working in part-time jobs and the money they received could barely be enough for them to support their family, so it is impossible for them to support their family. Secondly, bad communications between the couple are also one of the problems. This is because they have no understanding between them and it is always the misunderstanding that gets the best of them instead. This is why two ways of communication are important to everyone so that there would not be any problems at the end of the day but somehow people seem to take it for granted. Thirdly, divorce could also happen when people get married at an early age. Mostly, divorces happen because the young couple still not matured, and it is hard for them to understand each other. In this case, divorce is most likely to happen since a lot of problems occurred that young people could barely handle it in a matured way. So, as a solution, they choose to divorce to settle up their problems.

\section{Factors of Disapproving of Early Marriage}

Marriage is the legally or formally recognized union of two people as partners in a personal relationship (historically and in some jurisdictions specifically a union between a man and woman). Child marriage is any formal marriage or informal union where one or both of the parties are under 18 years of age. Each year, 15 million girls are married before the age of 18 . Child marriage is widespread and can lead to a lifetime of disadvantage and deprivation. According to Nour (2009), child marriage affects both boys and girls, though the overwhelming majority of those affected are girls, most of whom are in poor, socioeconomic situations.

\section{Financial Problem}

The financial problem is one the most critical problems that early married couple face. Most of the young couple divorced because of financial problems. This is because today's economic decline growth and it will give a big impact to the young couple. Moreover, nowadays most of the people are unable to get a stable job because of the limited opportunity. Most of the couple make materialism things become necessary. According to Anderson (2011), couples nowadays more valuing things more than the relationship. They felt like the household, furniture, jewelry and etc. is more important 
than their spouse. This thing will lead to a higher chance of the financial problem. They will have a lack of money after spending a lot of things that are not necessary. Besides, the extended family. According to McWhinney (2015), the extended family is a real problem when it comes to the financial problem. Imagine if the young couple marries at the early age around 18-25, and they still have their siblings to support them behind. It really costs them a lot of money.

\section{Missing Out Teenage Life}

According to Waters (2018), another factor is missing out on the fun of teenage life and being young if we get married at the early age. The relationship of young married couple can be easily fragile due to their immature minds. This affects the overall growth of individuals and in most of the cases, they do not turn up to be a responsible citizen. This might lead to health problems because they are always depressed and cause a great deal of stress which the couple has to go through when their minds are not capable to take them up. Based on Fuller (2017), teenagers are hardly grown up yet when they get married at the young age and this means that their behavior and attitudes sometimes tend to be childish. This immaturity can cause both partners to make decisions without thinking wisely. Immaturity can also get in the way of the marriage, as the couple begins to annoy with each other's attitudes.

\section{Lack of Responsibility}

In every marriage, either woman or man has their own responsibility and they have to fulfill the responsibility so that the couple will live together peacefully because each of them has their own roles to do. For example, a woman has to do house chores. That is actually a responsibility. Young couples who get married early do not know how to manage responsibility. They are still young in their mindset and still have to learn what a marriage is all about. According to Fuller (2017), the teenage years are a period of formation for young people, in which part is that they started to learn something like who they are and what they want. A teen couple will discover they are less right for each other than they had thought. Based on Top10For (2014), when the boys at the age between of 16 or 17 are burdened with a wife and he has to work to raise the family and in addition if he already has a child then, that might be a problem for him, then definitely he would find it to be quite hard to have a successful life.

\section{Mental and Health Problem Occurs Early}

Many parents think that young marriage will give the couple a very positive impact on them. But, in every action that you take, will have the bad effect. Those who married at the early stage will have both effects, such as psychological and physical effect. According to Pearson (2011), she said that girls under 18 who get married are more likely will have to experience the mental health problem. This will give them anxiety, depression and bipolar disorders. This health problem can cause them to consume more alcohol, drugs, and nicotine. According to Dr. Yann Le Strat, "With a 41 percent increased risk of mental disorder, child marriage should be considered a major psychological trauma," he added. According to Dr. Malik Haruna King (2013), those who involve in young marriage are still young and still growing. They have their own special immune, challenges and peculiar illness, being children. 


\section{Research Methodology}

The explanatory research was used in this research. According to Kowalczyk (2013), explanatory research is described as an attempt to connect ideas to understand cause and effect, meaning the researcher wants to describe what is happening. Explanatory research looks at how things come together and interact (Abdul Rauf et al., 2015). This study employed the quantitative study approach (explanatory study) to identify the pattern and magnitude of relations and interactions existing between the pre-decided of independent variable (unstable financial in young marriage, missing out teenage life, lack of responsibility and mental and health problem occurs early) and dependent variable (acceptance of people toward early marriage) The study involved 421 respondents and a cross-sectional survey and structured questionnaires were used for data collection. All variables were measured through scales previously used by other researchers.

\section{Results and Discussions}

\section{a) Profile of the respondents}

The profile of the respondents is discussed in terms of six characteristics: age, sex, occupation, religion and marital status. 
INTERNATIONAL JOURNAL OF ACADEMIC RESEARCH IN BUSINESS AND SOCIAL SCIENCES Vol. 8, No. 10, Oct. 2018, E-ISSN: 2222-6990 @ 2018 HRMARS

Table 1: Distribution of Respondents by Profile $(n=421)$

\begin{tabular}{|c|c|c|}
\hline Profile & Frequency & Percentage (\%) \\
\hline $\begin{array}{l}13-17 \\
18-25 \\
26-30 \\
31-35 \\
36 \text { and above }\end{array}$ & $\begin{array}{l}18 \\
373 \\
22 \\
0 \\
9\end{array}$ & $\begin{array}{l}4.3 \\
89 \\
5.3 \\
0 \\
2.1\end{array}$ \\
\hline $\begin{array}{l}\text { Sex } \\
\text { Male } \\
\text { Female }\end{array}$ & $\begin{array}{l}101 \\
320\end{array}$ & $\begin{array}{l}24 \\
76\end{array}$ \\
\hline $\begin{array}{l}\text { Religion } \\
\text { Islam } \\
\text { Hindu } \\
\text { Buddha } \\
\text { Christian } \\
\text { Others }\end{array}$ & $\begin{array}{l}407 \\
3 \\
4 \\
7 \\
0\end{array}$ & $\begin{array}{l}96.9 \\
0.5 \\
0.7 \\
1.7 \\
0\end{array}$ \\
\hline $\begin{array}{l}\text { Marital Status } \\
\text { Single } \\
\text { Married } \\
\text { Divorced }\end{array}$ & $\begin{array}{l}390 \\
28 \\
0\end{array}$ & $\begin{array}{l}93.1 \\
2.6 \\
0\end{array}$ \\
\hline $\begin{array}{l}\text { Occupation } \\
\text { Student } \\
\text { Government sector } \\
\text { Private sector } \\
\text { Unemployed }\end{array}$ & $\begin{array}{l}379 \\
7 \\
27 \\
8\end{array}$ & $\begin{array}{l}90 \\
1.7 \\
6.4 \\
1.9\end{array}$ \\
\hline
\end{tabular}

Table 1 above shows the profile of respondents who participated in answering the questionnaires given about early marriage in Malaysia. Based on the findings, most of the respondents who answered the questionnaires are aged between $18-21$ years old (89\%), female (76\%), students (90\%), Islam in religion (96.9\%) and single (93.1\%).

\section{b) Financial Problems}

Based on the table below, the highest mean for the items factors of financial problems is $\mathrm{M}=3.52$. This shows that most of the respondents think that not everyone is from the wealthy background. Besides that, the respondents also think that Malaysia's economy is unstable at the moment as the mean is $M=3.4$. It is stated in the Department of Statistic Malaysia itself that the economy in Malaysia 
INTERNATIONAL JOURNAL OF ACADEMIC RESEARCH IN BUSINESS AND SOCIAL SCIENCES

Vol. 8, No. 10, Oct. 2018, E-ISSN: 2222-6990 ㄷ 2018 HRMARS

is going downhill and if so, it may be impossible for young people to support their family needs in this economy.

Table 2: Financial Problems

\begin{tabular}{|c|c|}
\hline ITEMS & MEAN (M) \\
\hline $\begin{array}{l}\text { I believe that not everyone is from the wealthy } \\
\text { background. }\end{array}$ & 3.52 \\
\hline The economy in Malaysia is unstable & 3.4 \\
\hline $\begin{array}{l}\text { I believe that younger people have a lot of things } \\
\text { they desire. }\end{array}$ & 3.3 \\
\hline $\begin{array}{l}\text { I believe that younger people still rely on their } \\
\text { parents' financial. }\end{array}$ & 3.02 \\
\hline $\begin{array}{l}\text { Younger people do not have a proper job to } \\
\text { support his family. }\end{array}$ & 2.82 \\
\hline Overall & 3.2 \\
\hline
\end{tabular}

\section{c) Lack of Responsibility}

Table 3 shows that the highest mean is $M=2.90$ which the respondents believe that any girl will struggle to take care of the newborn baby at an early age. It also shows that the respondents agree with the statement, which makes those who are involved in early marriage are lack of responsibility. This follows with the mean $M=2.75$, which makes the respondents think that younger parents are still unclear about parental guidance. The lowest mean is $\mathrm{M}=2.40$ which our respondents think that a younger woman or parents may not be able to provide appropriate care for the child. 
INTERNATIONAL JOURNAL OF ACADEMIC RESEARCH IN BUSINESS AND SOCIAL SCIENCES

Vol. 8, No. 10, Oct. 2018, E-ISSN: 2222-6990 @ 2018 HRMARS

Table 3: Lack of Responsibility

\begin{tabular}{|c|c|}
\hline ITEMS & MEAN (M) \\
\hline $\begin{array}{l}\text { I believe that the girl will struggle to take care of } \\
\text { the newborn baby at an early age. }\end{array}$ & 2.90 \\
\hline $\begin{array}{l}\text { I believe that the younger parents are still unclear } \\
\text { about parental guidance. }\end{array}$ & 2.75 \\
\hline $\begin{array}{l}\text { I think the young boy will find it quite difficult to } \\
\text { have a successful life. }\end{array}$ & 2.64 \\
\hline $\begin{array}{l}\text { Younger age is not matured enough to carry big } \\
\text { responsibilities. }\end{array}$ & 2.61 \\
\hline $\begin{array}{l}\text { I believe that the younger woman/parents may not } \\
\text { be able to provide appropriate care for the child. }\end{array}$ & 2.40 \\
\hline Overall & 2.66 \\
\hline
\end{tabular}

\section{d) Missing Out Teenage Life.}

Based on Table 4, it shows that the highest mean for this factor is $M=3.1$ which the most agreed by the respondents. The respondents think that younger parents will be depressed thinking about their responsibilities in college and their family at the same time. This follows with the mean $\mathrm{M}=2.69$ which stands for the time to spend between the young couple and their friends will be neglected are chosen by our respondents as the second highest mean. 
INTERNATIONAL JOURNAL OF ACADEMIC RESEARCH IN BUSINESS AND SOCIAL SCIENCES

Vol. 8, No. 10, Oct. 2018, E-ISSN: 2222-6990 @ 2018 HRMARS

Table 4: Missing Out Teenage Life

\begin{tabular}{lc}
\hline ITEMS & MEAN (M) \\
\hline $\begin{array}{l}\text { Younger parents will be depressed thinking about } \\
\text { their responsibilities in college and their family at the }\end{array}$ & 3.1 \\
same time. & 2.69 \\
$\begin{array}{l}\text { I believe the time to spend with young couples and } \\
\text { their friends will be neglected. }\end{array}$ & 2.68 \\
$\begin{array}{l}\text { Teen couples are less right for each other than they } \\
\text { had thought after married at young age. }\end{array}$ & 2.65 \\
$\begin{array}{l}\text { I believe that mental disorder will occur at a young } \\
\text { age. }\end{array}$ & 2.55 \\
Young parents have no time for entertainment. & 2.73 \\
\end{tabular}

e) Mental and Health Problems Occurs Early.

Based on table 5, the respondents mostly agree with the first item with the mean of $M=3.34$. This shows that they agree that young people need to take care of their health before they turn old as they are still young and healthy. It also follows with the statement that girls are most likely to face health problems with the $M=2.77$. This means that everyone should take care of his or her health in every situation and basically young people who are still healthy and living life without any health problems should always make sure it maintains that way. And surely, every disease has its own cures. However, the overall mean is less than 2.5 which means majority disagree with this factor.

Table 5: Mental and Health Problems Occurs Early.

\begin{tabular}{lc}
\hline ITEMS & MEAN (M) \\
\hline $\begin{array}{l}\text { I believe that young people need to take care of their } \\
\text { health before they turn old. }\end{array}$ & 3.34 \\
$\begin{array}{l}\text { Girls are most likely to face health problems. } \\
\text { I believe that young people will get depressed if they get } \\
\text { married at a young age. }\end{array}$ & 2.77 \\
I believe that they will get to suffer from STDs (sexually \\
transmitted diseases) especially HIV and HPV. \\
$\begin{array}{l}\text { I believe that the young girl will face death if they get } \\
\text { pregnant before the 20s. }\end{array}$
\end{tabular}


INTERNATIONAL JOURNAL OF ACADEMIC RESEARCH IN BUSINESS AND SOCIAL SCIENCES

Vol. 8, No. 10, Oct. 2018, E-ISSN: 2222-6990 @ 2018 HRMARS

\begin{tabular}{lcc}
\hline \multicolumn{1}{c}{ Component } & No & Mean \\
\hline Financial Problems & 421 & 3.2 \\
Missing Out Teenage Life & 421 & 2.73 \\
Lack of Responsibility & 421 & 2.66 \\
Mental and Health Occurs Early & & \\
& 421 & 2.48 \\
\hline Overall & & 2.77
\end{tabular}

Table 6: Summary

\section{Conclusion}

Based on Table 6 above, it shows that the component with the highest mean is financial problems with $\mathrm{M}=3.2$. Most of respondents agreed with the statement everyone is not from a wealthy family and cannot afford to marry at early age. Meanwhile, based on the statement that younger parents will be depressed thinking about their responsibilities in college and their family at the same time which is linked to the missing out teenage life component makes the component as the second highest mean with $M=2.73$. All components show very high mean except for mental and health component $(\mathrm{M}=2.48)$. From this finding, researcher can conclude that majority people in Malaysia disapprove of early marriage and did not get support from family members.

\section{Acknowledgement}

Researchers would like to say thank you to Deputy Rector of Research in UiTM Cawangan Melaka, Associate Prof Dr Shafinar Ismail and Melina Mahpuz, Deputy Dean of Research and Industry Linkage from Faculty of Communication \& Media Studies, UiTM Shah Alam for their encouragement and motivation to do this research.

\section{Corresponding Author}

Abdul Rauf Ridzuan (PhD), Faculty of Communication \& Media Studies, UiTM Cawangan Melaka, Malaysia. Email abdulrauf@melaka.uitm.edu.my

\section{References}

Anderson, N. L. (November, 10, 2010). Forbes. Retrieved from Forbes: https://www.forbes.com/sites/financialfinesse/2011/11/10/5-financial-mistakes-that-ruinyour-marriage-2/\#45327cc1afa5

Bachofen, C. A. (1920). A commentary on the new code of the law. London.

Baptiste, D. (October, 11, 2010). Boldsky. Retrieved from Boldsy.com: https://www.boldsky.com/relatioship/marriage-and-beyond/2010/early-marriageproblems-111010.html

Dahl, G. B. (2010). NCBI. Retrieved from NCBI: https://www.ncbi.nlm.gov/pmc/articles/PMC3000061/

Demand, N. (1994). Birth, Death, and Motherhood in Classical Greece. John Hopkins University Press. 
INTERNATIONAL JOURNAL OF ACADEMIC RESEARCH IN BUSINESS AND SOCIAL SCIENCES

Vol. 8, No. 10, Oct. 2018, E-ISSN: 2222-6990 @ 2018 HRMARS

Chua Yan Piaw (2011). Kaedah penyelidikan edisi kedua. Kuala Lumpur: McGrawHill.

Cohen, J. (1988). Multiple regression as a general data analytic system. Psychological Buletin. 70(6), 426-443.

Early marriage (2018). Retrieved from https://www.k4health.org/toolkits/youthpolicy/earlymarriage-0

Fuller, S. (September, 27, 2017). oureverydaylife. Retrieved from oureverydaylife.com: https://www.oureverydaylife.com/disadvatages-teenage-marriage-8665995.html

Herbermann, C. (1907). Catholic Encyclopedia. New York.

Instah.(September 3, 2017). Instah. Retrieved from Instah Com: http://www.instah.com/relationships/top-7-disadvantages-of-early-marriage/

King, D. M. (July, 20, 2013). Ask Dr. Malik. Retrieved from withdrmalik.org: http://withdrmalik.org/2013/07/05-medical-problems-of-child-marriage

Kramer, R. (1993). The Jewish Family in Antiquity. Atlanta: Scholar Press.

Kowalczyk (2013). Purpose of research: Exploratory, descriptive and explanatory. Retrieved from http://educationportal.com/academy/lesson/purposes-ofresearch-exploratory-descriptive-explanatory.html\#lesson

Laiou, A. (1993). Coercion to sex and marriage in ancient and medieval societies. Washington DC.

Lamdan, R. (2000). A Separate People : Jewish Women in Palestine, Syria and Egypt in the sixteenth Century. Leiden.

Lowenstein, S. M. (2002). The Jewish Cultural Tapestry : International Jewish Folk Tradition. Oxford.

Modeus, G. and Blomkvist (2013). Social Media - Integrate it and Perfrom Better? Retrieved from www.diva-portal.org

M.A.Friedman. (1993). Jewish Marriage In Palestine, Vol 1, The Jewish Theological Seminary of America.

Mahidin, D. M. (2016). REPORT ON HOUSEHOLD EXPENDITURE SURVEY. PRESS RELEASE.

McWhinney, J. E. (September, 25, 2017). INVESTOPEDIA. Retrieved from INVESTOPEDIA: https://www.investopedia.com/articles/pf/09/marriage-killing-money-issues.asp

Nag, O.S. (April, 25, 2017). WorldAtlas. Retrieved from WorldAtlas: http://www.worldatlas.com/articles/child-marriage-rationale-historical-views-andconsequences.html

Pearson, C. (August, , 30, 2011). HUFFPOST. Retrieved from:https://m.huffpost.com/us/entry/941958

Sekaran and Bougie (2010). Research methods for business. A skill building approach. (5 ${ }^{\text {th }}$ Ed.). Great Britain: Wiley.

Spellberg, D. (1996). Politics, Gender, and the Islamic Past: The Legacy of A'isha Bint Abi Bakr. Columbia University Press.

Top10for. (February, 19, 2014). Retrieved from Top10for.com: http://top10for.com/top-10disadvantages-early-marriages/

Waters, I. (2018). Disadvantages of early marriage. Retrieved from https://oureverydaylife.com/disadvantages-early-marriage-8192592.html

Wimmer, R.D. \& Dominick, J.R. (2000). Mass media research An introduction. $\left(6^{\text {th }}\right.$ ed.). Belmont, CA: Wadsworth Publishing Company. 
INTERNATIONAL JOURNAL OF ACADEMIC RESEARCH IN BUSINESS AND SOCIAL SCIENCES

Vol. 8, No. 10, Oct. 2018, E-ISSN: 2222-6990 @ 2018 HRMARS

Yun, Y. X. (December, 17, 2014). Mstar. Retrieved from Mstar Com: http://www.mstar.com.my/berita/berita-semasa/2014/12/17/remaja-15-tahun-berkahwin/ 